\title{
Arrival in Austria. Heteronomy and Autonomy in THE EXPERIENCES OF REFUGEES
}

\author{
Monika MoKRE, Vienna
}

\section{Content}

1 Introduction

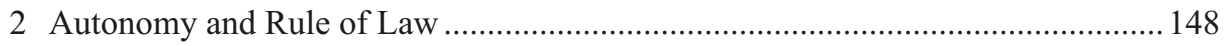

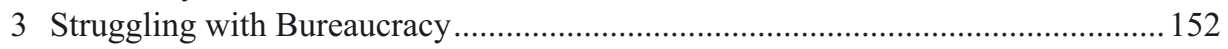

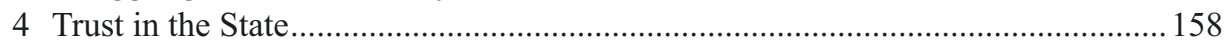

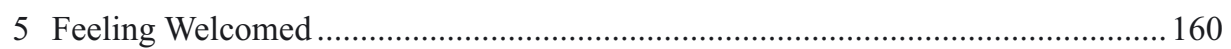

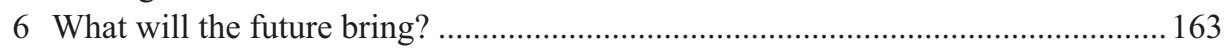

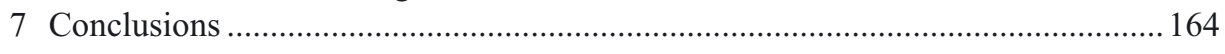

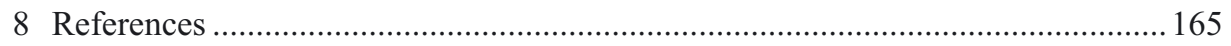

\section{Introduction}

It has been possible over the past 24 months to observe a radical change of discourse on refugee politics and, especially, the respective rights and duties of refugees and the receiving states in Germany and Austria. This nearly bipolar discourse taking its starting point from the moral duty of a welcome culture and leading rapidly to border closings, maximum limits for asylum applications, and decreasing social standards for refugees led to an equally bipolar political landscape in both countries, nowadays sometimes dubbed as a split society.

However, this is not a new development but has been observed several times over history when general acceptance and support for refugees was followed by rejection and fears (for Austria, see e.g. Liebhart \& Pribersky 2005; Zierer 1998, p. 140; STERN 
2008, p. 1068). To understand the current situation, one can draw on academic thought as well as more general political analysis developed in parallel to similar developments. Academic work on this issue can be divided into a normative, value-based strand or a pragmatic one. Or, to put it in another way, according to the two questions: What should be done for refugees and what can be done without endangering societal cohesion?

On the normative level, we can differentiate between universal norms for the equal treatment of people irrespective of their nationality and the norms that focus on national societies and states and their right to protect themselves. Obviously, these two forms of thinking about refugees (or also migration) are not mutually exclusive, but they clearly lead to different answers to the problem at hand (for an overview see, e.g., GibNEY 1999).

The overlap of these two strands of thought is, however, more obvious for the purpose of this article than in rather general considerations on this question. As this paper is empirically based on interviews with people who already entered Austria and aim to (and are, partly, also legally entitled to) remain in Austria, the question of who should be allowed to enter the country is not really of relevance here. Instead, the question at hand is: How can refugees design their lives in Austria, how can they integrate and be integrated in Austrian society?

According to the UNHCR (2013, p. 14) definition, "integration is understood as the end product of a dynamic and multifaceted two-way process with three interrelated dimensions: a legal, an economic and a social-cultural dimension. Integration requires efforts by all parties concerned, including preparedness on the part of refugees to adapt to the receiving society without having to forego their own cultural identity, and a corresponding readiness on the part of receiving communities and public institutions to welcome refugees and to meet the needs of a diverse population."

The Austrian National Action Plan (NAP) uses a similar definition by understanding "integration as a two-way process, which is shaped by mutual appreciation and respect, whereas clear rules secure social cohesion and peace. (...) An integrated society is characterized by social permeability and openness. Such a society allows individuals to shape their lives self-dependently, without being discriminated based on their origin, language or skin colour. Integration aims at participation in economic, social, political and cultural processes as well as compliance with related obligations." (BMEIA n.d. p. 2)

These political definitions are led by normative considerations not shared by a large part of public discourse that understands integration mostly as a form of assimilation; the obligation of refugees and migrants to adapt to the values and culture of the receiving country. However, these definitions also have a pragmatic component as they recognise societal dynamics brought about by migration. Thus, GiBney (1999, p. 173) plausibly calls for an "ethical ideal (which) pictures the state not as an agent that strives to maximize total global utility or has completely open borders but as an entity that strives to create a national community consistent with liberal egalitarian principles 
and that treats foreigners according to the same principles when doing so does not jeopardize the reproduction of these principles within its territorial boundaries."

On the basis of this understanding of the moral obligations of receiving states, this paper argues that liberal egalitarian principles are based on an understanding of human dignity dependent on autonomy, understood as the ability of each person to determine for themselves a view of their preferred life (TAYLOR 1992, p. 57). Taylor, furthermore, assumes that the recognition of equal dignity is closely linked to procedural liberalism, including the principle of a difference-blind procedure.

Obviously, the principles of equality and respect for human dignity are especially difficult to uphold with regard to extraordinarily vulnerable groups and, more so, in a time of potential overstretch of state capabilities. Still, this paper argues that it is according to these normative principles that the situation of refugees has to be assessed. Such an assessment includes knowledge of one's rights and duties and the possibility to deal with one's situation in an informed way.

However, integration relies not only on individual autonomy, but also on collective cohesion. This collective cohesion, usually and rather problematically dubbed collective identity has an external and an internal dimension. In contemporary, democratic nation states of the global North, the external dimension can be equated with citizenship, usually based on the construction of national belonging (see, e.g., GellnER 1983). This form of inclusion and exclusion has become more and more problematic in contemporary migration societies. Refugees share the democratically doubtful situation of all noncitizens in that they are not the authors of the laws to which they are subjected as they do not enjoy political rights. This poses an important problem for democracy. “(...) (I) $t$ is not realistic to say that in contemporary democracies the subjects of the law are also its authors. These changes in circumstances of politics make it likely that many democracies have become dominators, practicing what Walzer calls 'the oldest form of domination,' the domination of non-citizens by citizens.” (BoHman 2009, p. 540) Non-citizens only have duties but no rights and have, thus, according to Pettit a similar position as "slaves or serfs" (quoted after BoHman 2009, p. 545).

The internal dimension of collective cohesion is based on loyalty and trust to the state and cohabitants of the same territory (MOKRE 2002). This loyalty is not necessarily directly linked to possibilities of participation in political decision-making. Especially in the precarious situation of asylum seekers and refugees, individual experiences with a country and its citizens play an important role for the possibility to develop loyalty and trust.

Finally, expectations for one's own future are, on the one hand, to a large extent dependent on the above-mentioned variables and influence, and on the other hand, one's readiness to integrate in a society.

Against this theoretical background the interviews were analysed according to the following dimensions: 
1. Knowledge of one's own legal situation

2. Assessment of concrete institutions and organisations

3. Assessment of the Austrian state

4. Impressions of Austria and its population

5. Expectations for the future

The interviews were coded according to these dimensions; dimension 1 was coded using school grades (from 1, excellent, to 5, insufficient), all other dimensions were coded using the assessments "positive, negative, neutral, and ambiguous". For each interview, each code was assigned only once. However, in many cases, different assessments, i.e. codes, on the same dimension came up within one interview, e.g. when positive expectations for the future of the children were mentioned but negative expectations for one's own future. Thus, the sum of all codes for a dimension can be (much) larger than the number of interviews.

\section{Autonomy and Rule of Law}

This section is concerned with the rule of law as a presupposition of democracy which also has to apply to non-citizens - as Article Six of the Universal Declaration of Human Rights (1948) stipulates: "Everyone has the right to recognition everywhere as a person before the law". The section, thus, poses the question as to how far the principles of the rule of law apply to refugees and asylum seekers according to their own assessment. Lon Fuller has formulated eight formal principles for the "'inner morality of law':

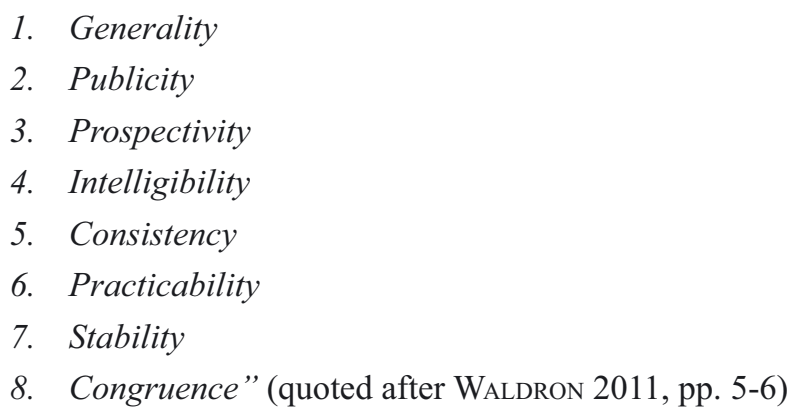

For Fuller, these principles are derived from the basic moral requirement of respecting human dignity (quoted after WALDRON 2011, p. 14). From this perspective, the principles of rule of law gain an individual quality, the law "conceives of the people 
who live under it as bearers of reason and intelligence. They are thinkers who can grasp and grapple with the rationale of the way they are governed and relate it in complex but intelligible ways to their own view of the relation between their actions and purposes and the actions and purposes of the state." (WALDRON 2011, p. 19). The universal right to freedom has to be "transformed into those capabilities, statuses, and powers necessary for effective participation and claim making in the legal system." (BOHMAN 2009, p. 553).

Out of these theoretical considerations, refugees and asylum seekers being informed about their rights, their legal status, and the consequences of decisions by the competent officials and courts has the potential to be of high impact.

\section{Figure 1: Knowledge of one's own legal situation}

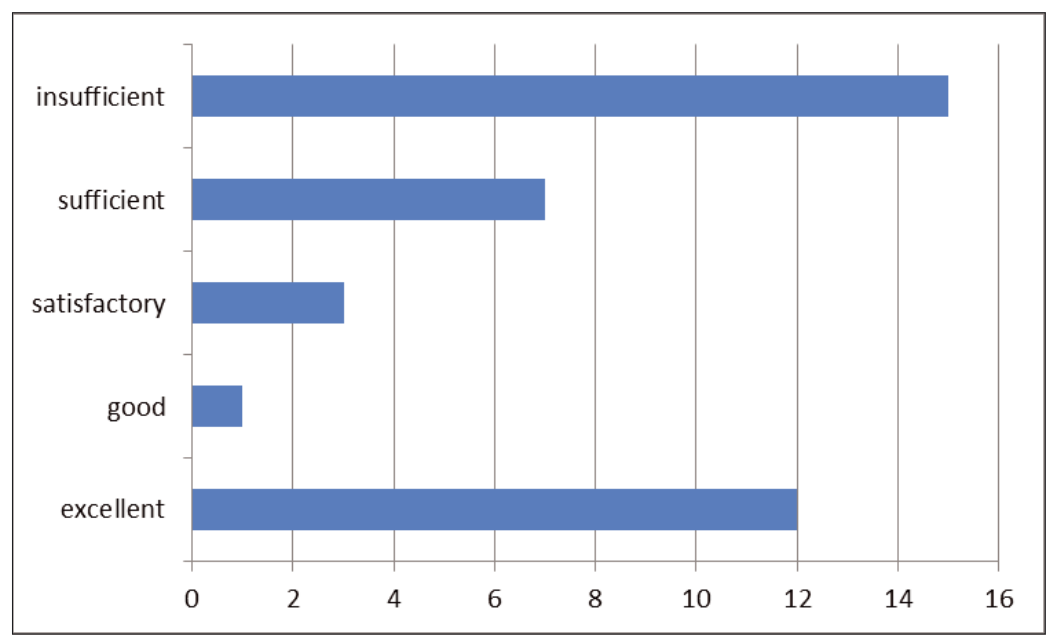

Statements about a person's own legal situation could be found in nearly all interviews, relating either to the actual situation or to descriptions of their initial experiences in Austria. As the results show, more than $25 \%$ of the interviewees made statements showing that they have or have had insufficient knowledge about their legal situation. The first experiences in Austria are frequently described as extremely confusing and traumatising:

"Suddenly, we were discovered by the police. They pursued us for some time until our driver gave up and stopped the car at the side of the road. The driver was arrested and we were brought out. (...) The police let us wait for about an hour. Gave every one of us a kind of tape with a number and a name. Yes, and then a policeman came. We do not know the Austrian flag, and when this policeman came, we thought that we were still in Hungary. Because of this we were all very intimidated and were afraid. We asked the 
policeman what would now happen with us and what our situation was. He answered that a bus would come for us and drive us to a camp in Vienna. When we heard "Vienna" we were relieved. The bus came and we got in. The ride lasted for three hours. But as the bus drove in the direction of Hungary, we thought, okay, this was that now. They lied to us and will bring us back to Hungary. There, we have to give our fingerprints and we have to stay there. We all trembled and our nerves were completely at edge. Before you enter Hungary, about 100 or $70 \mathrm{~km}$ before it is an Austrian police border control. There, the bus stopped. We were allowed to get out." (I3)

"I don't know, the coyote let us out, I had a bit of money, bought something to eat, I did not know that this was Austria, I was psychically very bad, then, they took me, they talked with the policeman, they brought a translator, I don't know, I thought I were in Greece, I did not know the language ..." (A 17)

At the same time, these quotations also show that the refugees were happy and relieved to be in Austria (and not in Hungary or Greece). As will be shown later, in spite of their difficulties, the interviewees hold a very positive image of Austria.

The time of arrival is for many refugees not the only period of confusion and lack of understanding. Legal procedures are unclear and in many cases not explained to them.

"I am here for about 7 months, and [ahem] till now there is no paper and no information about me, I am waiting I mean.” (S18)

"Honestly, I did not really understand what they wanted from me exactly. I was just sent to and fro without achieving any results. By the end of the day, I did not even understand what they want from me." (I10)

"There, they gave us the green card. I do not know why. My friend who came with us got a white one. Only my brother and I got a green. Why it was like this, no idea." I (I3)

This situation of confusion can lead to rather far-fetched ideas on the asylum system in Austria.

"S10: Two sons are in the meantime in Austria. They already got asylum. But I not yet. I do not know why.

Interviewer 1: Two sons have asylum but you not yet?

S10: Not yet. I have been here for 10 months and my children have already been here for three months and I think they take the young people, not the old people.

Interviewer 1: I beg your pardon?

S10: They take the young ones.

Interviewer 1: The young ones before the old ones?

S10: Yes, I think, the old ones, this is - ahem-expired. " (S10)

After an asylum application, a green card is issued confirming that the person asked for asylum but that Austria has not yet decided on his/her right to enter the asylum procedure in Austria. The white card confirms that a person is in the Austrian asylum procedure. 
Or, the situation is simply described as completely non-rational.

"In the camp in Traiskirchen weekly they make lottery and [Haz, Nasib](the same meaning of lottery), they draft and five persons took permanent residence exclusively singles who took the permanent residence, they shouldn't be married, the name that they were making the lottery on them, people took the residence in a day or two days, and people stay for a year or 7 months or 10 months, other people they went to the interview, the judge asked him, what is your name, he said to him [fulan] (which means someone name), they said to him go, and people were interviewed two hours and gave them temporary residence, I mean, luck in this country I couldn't imagine, luck, you and your luck!' (S5)

Lack of legal knowledge can also be perceived in several statements about their legal status referring to a "residence permit" or a "visa".

On the other hand, one has also to mention that nearly $30 \%$ have very good knowledge about their legal situation, among them people in the asylum procedure (green or white card) and people who already passed the procedure and have now the status of a refugee ${ }^{3}$, subsidiary protection ${ }^{4}$, a humanitarian right to stay $^{5}$ or a status of tolerance ${ }^{6}$.

One interviewee even admits that he knows how to use the system in a not entirely correct way.

"Normally, you do not have to say that but it is (...) It is like that, ahem, but, ahem, I get from the Caritas, when I live privately, money and also money for the rent, I have to pay rent. She (the apartment owner MM) said, you can keep that. " (S10)

One should mention here that asylum seekers living in private quarters receive $€ 205$ for their living costs including pocket money and, additionally, a maximum of $€ 150$ for the rent (FSW n.d.) ${ }^{7}$. As, obviously, it is not possible to live from $€ 205$, many people accommodating asylum seekers do not ask for rent. In terms of egalitarian principles, meeting the basic needs of asylum seekers seems problematic given that the basic income in Austria amounts to $837,76 €$ (wien.at n.d.). ${ }^{8}$

Two interviews also show that some refugees know about the conditions for asylum in Europe.

2 (Different forms of) residence permits are issued according to aliens' law but not asylum law. A visa entitles people to enter the country but not to stay there.

3 Due to individual political persecution.

4 Individual persecution is not assessed but protection is necessary due to the general conditions in the country of origin, e.g. war.

Neither the status of refugee nor the one of subsidiary protection is granted but a title due to humanitarian reasons, e.g. for integration, family reunification, or for victims of human trafficking.

6 For people who should be deported but are not accepted back by their country of origin.

See $<$ http://wohnen.fsw.at/grundversorgung/leistungen.html $>$

Figures for Vienna. 
"At this point in time, it was said that Hungary would close its border on September 15th, and everybody who would be caught would go to prison for three years. We heard from journalists in Macedonia that Croatia would open its borders. But the information was not confirmed to 100 percent. In any case, it should be treated with some caution. They recommended to try rather it via Croatia than via Hungary. We should try it and see. By the end of the day, me and my eight boys decided to try it via Croatia. " (I4)

"The situation was really very difficult. If the policemen had understood that we were Iraqis this would have been the end of us. As they usually send back Iraqis. Thus, they posed several questions about Syria to be sure that we were Syrians. As we knew all that beforehand, we learned some information about Syria by heart before we left. In any case, we passed the "test" and could move on. (...) If we had said that we were Iraqis we would have had to go back.

Interviewer: Why?

"Well, because they would bring us to the north of Iraq. The north of Iraq is quiet and peaceful in comparison to the rest of Iraq. But a Syrian? Where do you want to send a Syrian back to? As they cannot deport Syrians, the Syrians can stay. They give them an ID card and they can move on with this card. We also received such cards." (I3)

Mainstream discourse understands the use of this kind of knowledge for getting asylum (or for travelling through the EU) as asylum fraud. It is not the aim of this paper to morally judge the ways in which refugees manage to overcome bureaucratic hurdles in Europe. But, in any case, the example shows a superior knowledge of asylum conditions in the EU, enabling personal autonomy in choosing one's country of residence.

A few interviewees also mention that they help their fellow country people with bureaucratic questions. A Syrian woman who was a political activist in her country of origin is still politically active in Austria. She has a very good grasp of the legal situation here, also because of networks with Austrians in which she is active.

\section{Struggling with Bureaucracy}

An understanding of one's own legal situation is only a part of the information necessary to create a new life in a new country. In the precarious situation of seeking asylum, a wide range of support measures are needed in order for the asylum seekers to find their position in society and to be able - at least in the mid-range - to live an autonomous life. This begins with legal procedures to get asylum, but also includes lodgings and access to education and/or work. Thus, the interviews were also evaluated with regard to the experiences of the interviewees with the institutions and organisations they had to deal with. These experiences have, generally, led to a rather skeptical view of institutions and organisations. While this is not surprising as, in general, newcomers to countries are confronted with confusing procedures and institutional set-ups, still, the question arises of how this situation could be alleviated. 
Figure 2: Assessment of Institutions and Organisations

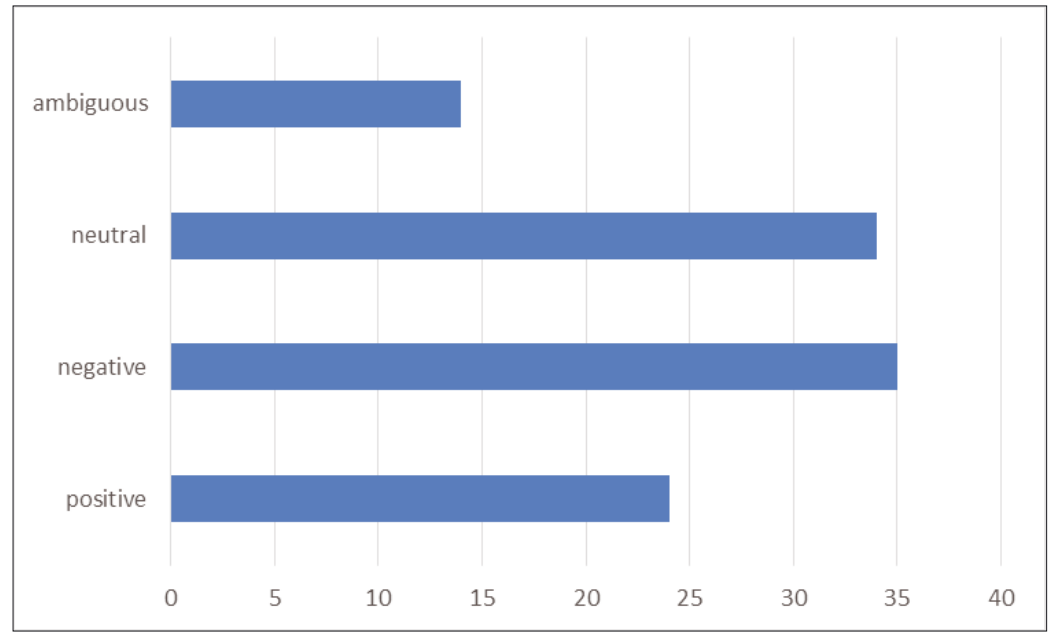

Iraqi interviewees show the most negative view of institutions and organisations.

Figure 3: Assessment of Institutions and Organisations according to Country of Origin

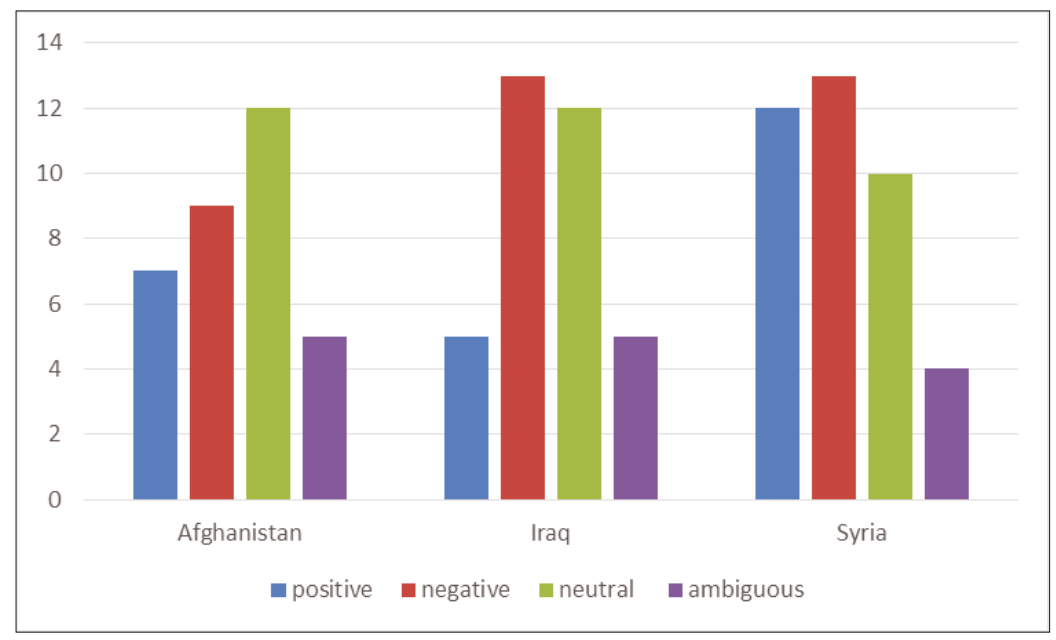

For those in the asylum procedure and, especially, those who have been in this situation for a long time, this procedure poses the most serious problem. 
"I have been here now for six months but, up to now, I have not been invited for an interview. I was so surprised about that. At one point, my nerves were so on edge that I was prepared to return voluntarily to Iraq. I told it to them. When there is no hope here for me I can, at least, be useful in Iraq. There are the children of my brother, all alone, orphans. My own family as well. Then, I can take care of them and do something useful. But, yes, I am only put off all the time. It takes as long and I shall be patient. Patient and patient and patient again. Yes." (I6)

And, also, lack of respect in the procedure is mentioned by the interviewees.

"Yeah, for the people they didn't know, they know about your number, you are a number for them, you are a refugee. He didn't look about your background from where you are coming, from which kind of the society, from which level of education (...)." (S13)

But even after a positive end of the asylum procedure, many bureaucratic problems arise, above all for people who are not recognised as refugees ${ }^{9}$. Frequently, they feel subjected to arbitrary treatment by individual officials.

"I went to her in the passport department, she said to me that any man has a Syrian passport, he has no Austrian travel document, I asked her a question, how can the one go and come back? She said you go using the Syrian passport, I said to her and how do I come back? She said as you came. What does that mean, as you came, that means I came back smuggling, she said as you like. I said to her, oh Miss I have the right to a passport, temporary its colour is red for a year the one who has an annual residence and the one who has a residence of two years is for two years. She said I don't want to give you (...)." (S5)

Also several other issues play an important role for the possibility of refugees to integrate into society. This starts with the conditions at their arrival as also stipulated in the EU-directive on standards of reception (DiRECTIVE 2013/33/EU, Art.17, §2): "Member States shall ensure that material reception conditions provide an adequate standard of living for applicants, which guarantees their subsistence and protects their physical and mental health."

In the interviews, we can find detailed descriptions of the bad conditions at arrival and in provisional camps.

"We could go wherever we want, they told us. But where should we go? There was neither space nor a room where we could retreat. In the camp, there were 4500 persons. One could not even find a place in the garden. Finally, we found some place next to the toilets. (...) When there was heavy rain and the water reached the tents, we changed into the buses. There were buses organised for that in Traiskirchen. (...) The food in Traiskirchen was really terrible. A real torture. Not edible. And when you criticised the food, immediately, the question came, why did you come at all? Stay in Iraq. "

$9 \quad$ Recognised refugees are entitled to a convention passport; people with all other forms of permission to stay only get a passport as an exception of the rule. 
This assessment comes out of the time of a huge influx of refugees for which Austria was unprepared. The situation before and after the summer and fall of 2015 has been much better - although, frequently, still not satisfactory.

\begin{abstract}
"In the beginning, it was a to and fro. I did not leave out a single police station to present myself. All sent me away as everything was full. They sent me to Traiskirchen and when I arrived in Traiskirchen they sent me to Vienna as they were over-occupied. It was like this for three days. (...) By chance I met an Iraqi family who gave me an advice. They recommended going to the main station. They said there is also a police centre. I went there. Finally, it worked. Of course, I had to go to prison for three days. The food was really very minimalistic. They woke me at 5am. to weigh me. (laughs derisively) After three days, the policeman came and said that I could go now. I asked him if he could give me an address where to go. He only said: "You are free - Go. "He neither helped me nor did he give me an address. " (I7)
\end{abstract}

Obviously, such procedures are not only painful for individual refugees but, also, harmful for Austria as legalisation and, thus, also the possibility to integrate into society are hampered and delayed.

Apart from the rather extreme situation in overcrowded and, partly, provisional camps, the interviews show that conditions are frequently not satisfactory with regards to food, clothing, German courses, and internet connection. It is also mentioned some times that these deficits cannot be compensated by the refugees themselves as they do not receive enough pocket money while staying in official housing for asylum seekers.

"After Althofen we had to go to Rettenheim, a small village up on a mountain in Carinthia. (...) The director of the pension (...) was a really terrible and mean person. Gave us expired food. (...) There was no kitchen or microwave. We could not cook. (...) We were not allowed to visit each other in the room. (...) Smoking was completely forbidden. Not even on the balcony or in a smoking room or in front of the pension in the yard. "(I3)

The situation is especially problematic for people with some specific needs, although EC legislation also exists for these cases (Directive 2013/33/EU, Art. 21):

"Member States shall take into account the specific situation of vulnerable persons such as minors, unaccompanied minors, disabled people, elderly people, pregnant women, single parents with minor children, victims of human trafficking, persons with serious illnesses, persons with mental disorders and persons who have been subjected to torture, rape or other serious forms of psychological, physical or sexual violence, such as victims of female genital mutilation, in the national law implementing this Directive." 
The interview with a Syrian woman with three children shows that the vulnerability of specific groups of refugees has not been taken into account.

"Then they transferred me to Fieberbrunn in Tirol, 800 meter above sea level. (laughs) So, and then with the three kids, it was actually so hard to be there, because there is no transportation, no, nothing, nothing, nothing, just mountains and sky and I stayed there around one month and a half. " (S13)

Also, a woman with cancer complained about the lack of adequate housing.

"I began to look for an apartment. I went to Caritas and Caritas found apartments not adequate to my state of health, e.g. an apartment on the $6^{\text {th }}$ floor without lift. (...) The search for an apartment lasted for four months. I was out and about from morning till evening and have visited apartments and went from one agent to the next." (I12)

With regard to education, above all, the lack of German courses poses a problem to the refugees - in spite of the fact that the National Action Plan of 2010 (BMEIA $\mathrm{n} / \mathrm{d}$, p. 12) emphasises the importance of German language knowledge for integration. "Mastery of the German language is also a precondition for participation in economic and societal live. The promotion of the German language and the continuous further development of the education system are an essential precondition for success in the education system and the later integration into professional live. Whoever wants to live permanently in Austria and to participate in economic and societal life must be prepared to learn the German language."

So, for instance, in a position paper of April 2016, the Austrian Association for German as Foreign/Second Language described the situation in German courses financed and organised by the Labour Market Service (AMS) as highly problematic - hours for German courses were reduced, teachers faced an enormous workload for very little salaries, and due to lack of trainers, also teachers without the necessary education were employed (Österreichische Vereinigung fÜr Deutsch als Fremdsprache/Zweitsprache 2016). Since then, the situation has improved but, still, there are large discrepancies in the quantity and quality of German courses between the Austrian provinces (SOS Mitmensch 2017).

"I have a request, namely, the Austrian government should give us the possibility for education, so that we can learn .... Up to now, we have not received any help since we have lived in Austria, the Austrian government has not helped us at all. There are only some people coming to the camp to teach us the German language, apart from that, we do not have anything." (A3)

At the same time, in many Austrian offices, clients are required to speak German. 
"I manage myself sometimes with English, but you know as an Austrian - Austrian people, they didn't prefer to talk in English and even in the, in Ämtern (offices, MM), they didn't. If you go to any, any official place and you begin to speak in English they immediately (...) Close, yeah. They didn't accept it in any way. In Sozialamt (social welfare office), in AMS (labour market service), what I used to go, because to doing my paper, they didn't accept to speak English. They prefer miming to speaking English, yeah (laughs)." (S13)

As to possibilities to work, asylum seekers are in a highly unfavourable position. By law, Austria exceeds the EC directive (2013/33/EU, Art.15, §1) stipulating that asylum seekers should be allowed to work after nine months as asylum seekers can get a work permit three months into the asylum procedure (AUSLÄNDERBESCHÄFTIGUNGSGESETZ, § 4, 1). However, not only do the conditions for such a work permit pose many challenges to potential employers and employees, the law is furthermore qualified by a ministerial decree from 2004 stipulating that asylum seekers can only be employed in seasonal occupations (BMWA 2004, pp. 6-7). Asylum seekers are allowed to be self-employed, but for many self-employed professions a specific education is needed. They can do voluntary work (GRUNDVERSORGUNGSGESETZ, \$7,1), this law has been recently specified (BMI 2016) and, thus, it could be expected that this form of occupation will gain more importance in the future. For this work, a "recognition contribution" has to be paid (€3 to $€ 5$ per hour).

Even when the asylum procedure is positively concluded and people have free access to the labour market, it is frequently not easy to find an adequate job.

"There is no possibility for me to work or to learn the language, the Austrian government did not give us any possibilities. Since I have been here, they want me to work on the lowest level and I never did this kind of work in Afghanistan. Even though I brought my certificates here to AMS and told them to show me a possibility, they gave us language courses but they do not offer us possibilities to use here what we learned in Afghanistan." (A9)

"I don't know. I really tried everything possible but, still, it did not work out. I also went to AMS (labour market service). I was in different offices but, still, the nostrification did not work out." (I10)

I18 summarises in a very plausible way how all these difficulties to lead a normal life in Austria, in fact, lead to disintegration:

"So let's say I don't speak any English. They throw me off. They send me home. They don't give me any work. They don't give me anywhere to study or learn any German. What languages do I speak? Let's say I only speak Arabic. Who am I going to mix with? I'm only going to mix with the Arabic crowd. And then I'm gonna wait for my asylum process and that's gonna take let's say a year, and a year passes and I haven't done anything, I haven't learned any German and I am just home hanging out with my Arab friends and I'm not gonna be interested in having any Austrian friends. And so we gonna have our circle of just Arab-speaking people. And then they complain about lack of integration, they 
complain about "oh, why are they in their own circle". Well, why haven't you done anything to counter that, why haven't you given them a key to enter society, to integrate, to get to know other people. How else shall we help this new country that we are part of?" (I18)

However, also some very positive assessments could be found.

"The police treated me very well, good people, good policemen, people, they treated me well, they brought me to a camp, clothes, food, medication, on the way, I got sick ... then, they brought me to a camp, then to an apartment, they gave me monthly money and food, everything. My boss treated me well, the policemen as well, up to now, when I have problems, they solve my problems. "(A15)

"We were received by an Egyptian translator. He said: "Very welcome in your second home country Austria - don't be afraid. They will not send you back to Hungary. You can be sure of that." (I3)

"In Afghanistan ... they attacked me... the attack took place in front of my house door, due to this I lost vision in my right eye, two fingers are paralysed, they were operated on in Graz ... Also, my eye was operated on in Graz ... and I am very satisfied with this country. I get German courses, I learn the language, I do not have religious problems ... “(A4)

\section{Trust in the State}

Interestingly, the interviewees see the Austrian state in general in a much more positive way than the specific institutions and organisations they are dealing with. It seems that many refugees have kept their trust in a democratic state and rule of law in spite of their own, frequently negative experiences with procedures, institutions or organisations.

"All people are treated equally irrespective of where you come from. Everybody has the same rights and duties. A country where human rights are respected and apply. I really have to say, I have a lot of respect for this country." (I2)

Frequently, this assessment is also combined with critique of the corruption in the country of origin.

Negative assessments are rather linked to the specific situation of refugees or also an individual situation. 
Figure 4: Assessment of the State of Austria

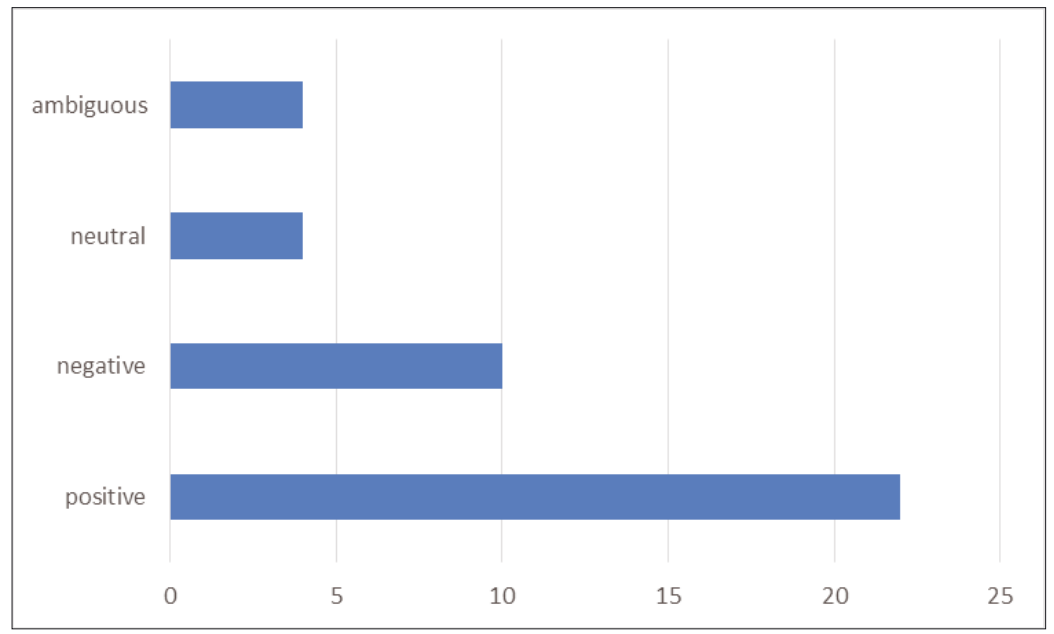

Positive assessments of the state are more than double the negative ones. Afghani interviewees especially have a very positive view of Austria.

Figure 5: Assessment of the State of Austria according to countries of origin

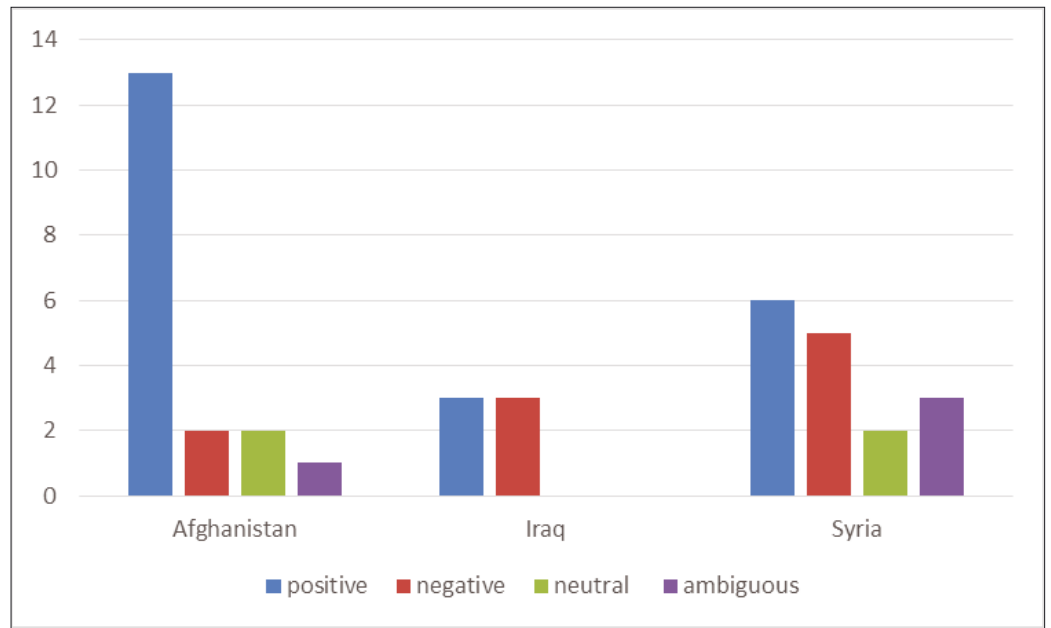

Above all, the interviewees emphasise their trust in the rule of law. 
"Austrian politicians want to make Austria unattractive. (...) That's exactly what they are doing right now. I have spoken to a young Afghani guy, a cute and smart guy and he said, he is returning to Afghanistan because he has given on his issues here. He knows, he will be killed by Al Qaida, because he had left, because he refuses to join them. Now, that they know that he had made it to Austria and he had to come back, that would give them another reason to kill him. Why do you send someone like that back? The threats on his life are now even more. That has to be addressed. "(I18)

Some of the interviewees also take a political stance towards newer developments in Austrian asylum policies such as impediments to family reunification or the fortification of borders.

"Then, you know, sometime they said for the family gathering" they make it a problem, for they, the border they make it a problem and they want to build fence or something, once I heard. But this will not stop the refugees when they are running for their life, nothing will stop them. If you put fence or, you will, they will fly or dig the floor to reach. So, now for the family gathering this is something inhuman. Because sometime the, the people, like the man or the woman they sell the house and they lend money and she sell whatever she can to [let] one of them travel, then to be safe and then to make family gathering for others. When they stop it, [the family reunion] how she will live there, with the kids? The husband here and she is there with the kids waiting to be with her husband? " (S4)

From personal experience, specific political critique also develops, e.g. in the case of a woman who was looking for an adequate school for her children. She faced the problem that children are usually required to visit the school nearest to their home address, but also saw other aspects of the Austrian school system as improvable.

"In Austria they always, they talk about integration, to mix the people together, to mix, why you judge me to be in the, as they name the $10^{\text {th }}$ district, the "Ausländerdistrict" (foreigner district), why you judge me, because I didn't find in all Vienna place, just in $10^{\text {th }}$ district, you judge me that you are not allowed to go out of this district. (...) The way they educate our kids it's a very very good way, but something, some point is missing, in, in, because they have to decide after four years, that mean 10 years old, they are so small, small to this big decision, that I will be after 12 years (laughs) engineer. Or I will be after 12 years a farmer. 12 years." (S13)

\section{Feeling Welcomed}

When integration depends inter alia on the "readiness on the part of receiving communities (...) to welcome refugees and to meet the needs of a diverse population" ${ }_{10}$ The interviewee is talking about family reunification. For recognized refugees, family reunification has become more difficult by the last amendment of Austrian asylum law. People under subsidiary protection have to wait for three years for family reunification 
(UNHCR 2013, p. 14) it has a strong impact on future integration if refugees and migrants feel welcomed in their country of residence. In the data analysis, this dimension has been addressed through the assessment of the country and its inhabitants.

\section{Figure 6: Assessment of Austria and its Population}

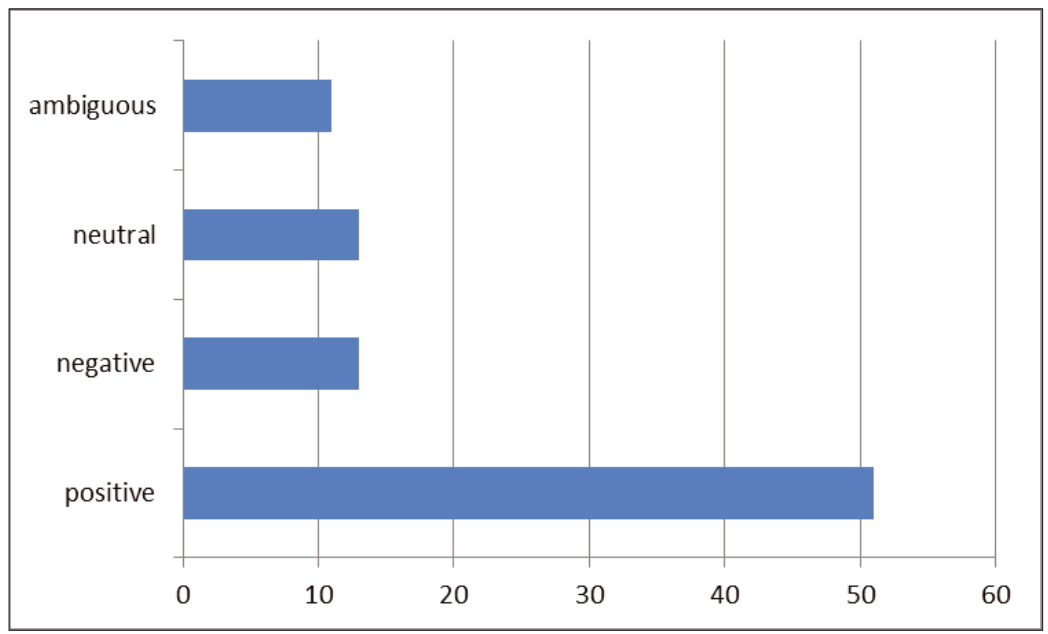

As we can see, the vast majority of the interviewees has a positive image of Austria and its population - in fact, the image is much more positive than the one of the state and its institutions. This holds true for the interviewees of all three nations. Probably, these very positive assessments of Austria are related to the fact that many of the interviewed refugees arrived during the period of the so-called welcome culture and were interviewed shortly after this time.

"The first day when we arrived - ahh, they supported us a lot, arrived at the Western railway station, e.g. they bought for the refugees, the children, food and distributed it or they bought clothes for us ... "(A6)

"I saw that Austria has especially much compassion for asylum seekers and refugees, much more than in other countries and, thus, I decided to come to Austria. "(I 12)

One of the interviewees also mentions the two-way-process of integration emphasised by UNHCR as well as the NAP - even in a very strict way of integration:

"One has to know how to behave. After all, we are guests in their country and have to follow their rules and laws. When you follow them and know how to behave, then the Austrians are also correct to us. But when you cannot follow their rules and laws, well, then, of course, they will also not treat you well. It is like that." (I6) 
And several of the interviewees criticise other "foreigners" in Austria.

"People are very peaceful... everything is peaceful. I cannot get along with foreigners, with Austrians I get along, they treat me very well. I am not satisfied with foreigners. " (A4)

"The Syrian Arabs were really good people but these Moroccans ... we could not sleep during the time as we were afraid to be robbed. Mobile phones, clothes, shoes, there was nothing which was not stolen. I do not understand why they come here. They do not have any problems in their country. I know from other people that they are only here for the heck of it. I am here and I realise that I have a bad reputation. Why do I have a bad reputation? These people coming from Algeria, Tunisia or Morocco, or even from some cities in Iraq, e.g. from Baghdad, they do not have any problems, they have a good life, they only come for fun. They talk stupidly to girls and women. And in this way, they also destroy my reputation because the other ones think I am like them. "(I13)

However, one of the interviewees also offers a rather thorough critique of the claim that refugees should assimilate in Austria. In fact, in his statement, he clearly differentiates between assimilation (the one-sided adaptation of minorities to the majority), and integration (the inclusion of minorities into an open and pluralistic societal system) (cf. Soziologie Heute 2008).

"It's about respect for, for yourself and for people itself. And it is not about that you should change your tradition in your country, no. But it's also to understand what's the tradition of those people? These people they have also traditions they have, and, and, they have many, many good things, you know. Nobody thinking about. They should change, they are here. I mean, this is, things you know, these things I think it is not good, not for both sides. Those people are here and if they want and don't want this is the, the Austrian citizen, the future of Austrian, a lot of Austrian citizenship in future." (S6)

And also, in quite a few of the interviews we find problems to adapt to the way of life here and mourning for the customs of one's country of origin.

"It is true that this country is very progressive but, here there is next to no social contact between people. There is no attention for each other, no empathy or sympathy for other people. There is no friend who is suddenly knocking at the door to drink a coffee together. Being a stranger does not only mean that one is living in a foreign country. Being a stranger is a feeling, it means loneliness, a deeply felt loneliness. " (I12)

"I feel, I don't know, I don't belong here; I don't belong there also (laughs)." ('

Sometimes, also racism by Austrian is mentioned but, mostly, in an attenuating way.

"And, yes, I know, of course, there are some Austrians who are against foreigners or refugees, but those are only a few. The majority of the Austrians is not like that." (I2) 
However, we also find some more negative assessments, also showing how people are pushed towards extreme political positions due to being excluded by majority society.

"You are terrorist. The student was talking like this: You are terrorist. (...) and then I said: "I really now understand those people who, who they, they commit suicide who they bombing themselves. I really now understand Atta (he refers to Mohammed Atta), the Egyptian guy who draw the flight and attack in United States. If he has this people in United States to tell him all the time: 'You are terrorist.' And when he has a chance to kill them, he will do it. And I told them: 'If I have now a bomb with me, I will bomb myself.' It's not because I want to do it, you know. But because what you are doing (...)." (S6)

Finally, it should be mentioned that the interviewers explicitly asked for an assessment of the open, liberal, and multi-cultural character of Austrian society - and the answers to that were unanimously positive.

\footnotetext{
"My impression of that is very good. You can say that really all nationalities are represented in Austria and this is very good. Different nationalities and religions live peacefully together in one place. In comparison to that, in our home country, in spite of the fact that we are all Iraqis, we do not live together peacefully. This shows a high level and it is really wonderful that this works so well in Austria." (I9)

"Austria seems to be very open with regard to religions, up to now, nobody has disturbed me, nobody has forced me to convert or not to pray, at this time, it is very open and I did not experience anything." (A9)
}

\section{What will the future bring?}

The interviews were also evaluated with regard to the expectations of the interviewees for their future. However, there was no explicit question on this issue; people were asked about their hopes for the future but not for concrete expectations. Thus, also the number of positive, negative, or ambiguous responses was rather low; dreams and hopes without any assessment of their probability were coded as neutral.

Nearly all interviewees with positive expectations for their own future had also had positive experiences up to now. However, even those with negative expectations have mostly positive assessments with regard to all other issues. Thus, no significant relation can be discerned here.

Rather, expectations for the future are concretely related to the present situation. In this vein, several interviewees with positive expectations are already working or studying or have concrete plans in this regard. Negative expectations come frequently out of a lack in legal security, e.g. in the case of one interviewee with the (very insecure) 
status of toleration or in another case, probably of subsidiary protection ${ }^{11}$. The latter interviewee sees opportunities for himself to master his life in Austria, but is afraid of being deported when his status is withdrawn.

Figure 7: Expectations for the future

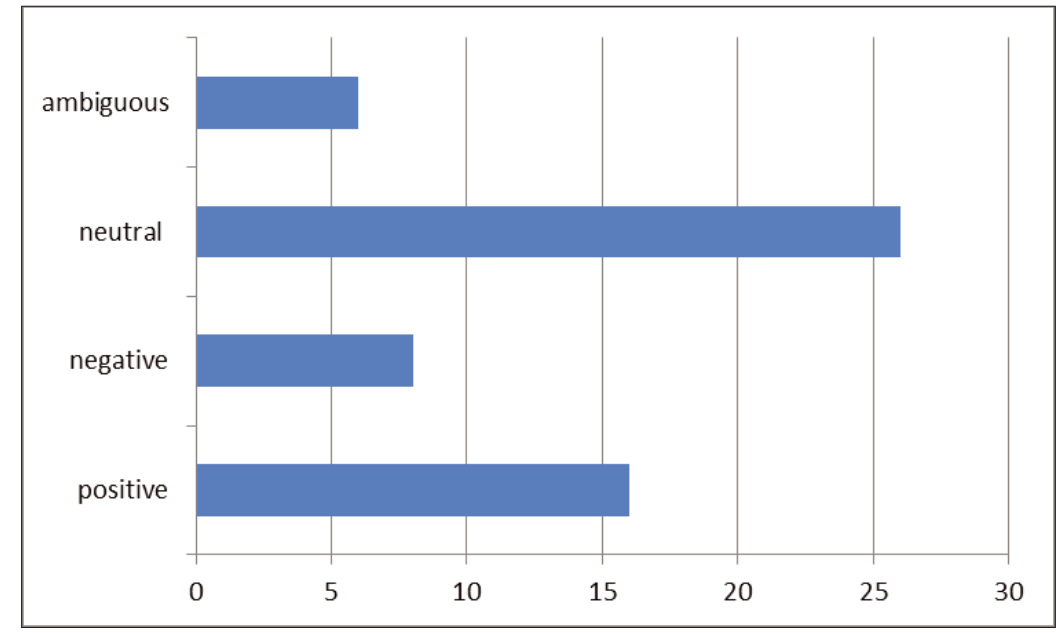

Other ambiguous statements on the future result from a combination of hopes for one's own career with fears for the family in the country of origin or, conversely, hopes for their children in Austria, but an expected career disappointment for the interviewee himself.

\section{Conclusions}

This analysis of the interviews has to be dealt with with caution due to several reasons. For one, they are based on a pilot study with a limited number of interviewees and no refined sampling procedure. Secondly, they deal with issues which, partly, were not at the core of the interviews. Thus, the paper should be understood as a very first inquiry into these issues which could form a starting point for further research.

However, even if the analysis is not representative, it shows some interesting results and, more importantly, some crucial problems of the Austrian asylum system which should be dealt with - even if, they only concern some of the refugees coming here.

11 This was not completely clear from the interview. 
Based on everyday mainstream discourse it is possible to conclude that growing fears and xenophobia from the Austrian population pose a major problem to refugees. However, at least at the time of the interviews, Austria and its population were mainly seen in a very positive light. The main problems refugees met were related to the way in which their legal status and their lives were organised by state institutions and staterelated agencies.

The necessity to improve these structures and procedures can be argued on a legal basis ranging from international conventions and EU law to national legislation and action plans. It is also related to more general moral obligations to refugees or, even, to everybody entering the Austrian territory. Above all, everybody should be informed about their rights and procedures must be known and intelligible to everybody concerned. In the case of asylum seekers dependent on several public services, this requirement does not only apply to their legal status but also to their rights to welfare, education, and work.

There are, however, also obvious pragmatic reasons for structures and procedures that allow for quick integration into society. In spite of right-wing incantations of closed borders and societies (and irrespective of the question of whether such societies are seen as desirable or not) contemporary societies are migration societies and will remain so. Thus, social cohesion can only be upheld and further developed when newly-arriving people have the opportunity to live an autonomous life as soon as possible.

\section{References}

AusLÄNDERBESCHÄFTIGUNGSGESETZ, <https://www.ris.bka.gv.at/GeltendeFassung.wxe?Abfrage= Bundesnormen \&Gesetzesnummer $=10008365>$

BMEIA n/d,. Nationaler Aktionsplan für Integration. <https://www.bmeia.gv.at/fileadmin/user_ upload/Zentrale/Integration/NAP/Bericht_zum_Nationalen_Aktionsplan.pdf $>$

BMI (2016), Sobotka: Leistungskatalog für Hilfstätigkeiten von Asylwerbern erstellt $<$ http:// www.bmi.gv.at/cms/bmi_asyl_betreuung/_news/bmi.aspx?id=4C62436A587450676C495 13D\&page $=1 \&$ view $=1>$

BMWA (2004), EU-Erweiterungs-Anpassungsgesetz; Durchführungserlass. <http://www.asyl.at/ fakten 2/EU-Erweiterungs-Erlass Bartensteinerlass.pdf>

Bohman J. (2009), Living without Freedom: Cosmopolitanism at Home and the Rule of Law. Political Theory, Vol. 37, No. 4, (August 2009), pp. 539-561.

Directive 2013/33/EU of the European Parliament and of the Council of 26 June 2013, laying down standards for the reception of applicants for international protection (recast). $<$ http:// eur-lex.europa.eu/legal-content/EN/TXT/PDF/?uri=CELEX:32013L0033>)

FSW (n.d.), Leistungen der Grundversorgung Wien. <http://wohnen.fsw.at/grundversorgung/ leistungen.html $>$

Gellner E. (1983), Nations and Nationalism. Ithaca: Cornell University Press. 
Gibney M.D. (1999), Liberal Democratic States and Responsibilities to Refugees, The American Political Science Review, Vol. 93, No. 1 (Mar. 1999), pp. 169-181.

GrundVERSORGUNGSGESETZ, (<https://www.ris.bka.gv.at/GeltendeFassung.wxe?Abfrage=Bundesn ormen\&Gesetzesnummer $=10005762>$

Liebhart K. \& Pribersky A. (2005), Brücke oder Bollwerk? Grenzland Österreich-Ungarn. In: Brix E., Bruckmüller E. \& H. Stekl H., Memoria Austria II. Bauten, Orten Regionen. Wien, pp. 411-441.

Mokre M. (2002), Identities and Representation. On the Development of a European Democracy. IWE Working Papers 33. <https://eif.univie.ac.at/downloads/workingpapers/IWE-Papers/ WP33.pdf>

Österreichische Vereinigung für Deutsch als Fremdsprache/Zweitsprache (2016), Stellungnahme zu den Lehr- und Lernbedingungen in AMS-Deutschkursen. <http://www.oedaf.at/ dl/MklkJKJlkNJqx4KJK/OeDaF_Stellungnahme_AMS-Deutschkurse.pdf $>$

SOS Mitmensch (2017), Deutschkurse für Asylsuchende: Frappante Unterschiede zwischen Bundesländern. $\quad<\mathrm{http}: / / w w w . s o s m i t m e n s c h . a t / d e u t s c h k u r s e-f u e r-a s y l s u c h e n d e-e i n-$ bundeslaendervergleich>

Soziologie Heute (2008)., Integration, Assimilation, Segregation. <https://soziologieheute. wordpress.com/2008/12/28/assimilation-integration-segregation/>

Stern S. (2008), Die tschechoslowakische Emigration: Österreich als Erstaufnahme- und Asylland. In: Karner S. (ed.), Prager Frühling. Das internationale Krisenjahr1968. Graz, Wien, Klagenfurt, pp. 1025-1042.

TAylor C. (1992), Politics of Recognition. In: Gutmann A. (ed.) Multiculturalism and the "Politics of Recognition”. Princeton, NJ, pp. 25-73.

UNHCR (2013), Facilitators and Barriers. Refugee Integration in Austria. Vienna, UNHCR $<$ https://fluechtlingsdienst.diakonie.at/sites/default/files/fluechtlingsdienst/files/unhcr-riceaustria-en_web.pdf>

Universal Declaration of Human Rights (1948), <http://www.un.org/en/udhrbook/pdf/udhr_ booklet_en_web.pdf>

WALdRon J. (2011), The Rule of Law and the Importance of Procedure. Nomos, vol. 50, Getting to the Rule of Law (2011), pp. 3-31.

wien.at (n.d.). Mindestsicherung. <https://www.wien.gv.at/gesundheit/leistungen/mindestsicherung/>

Zierer B. (1998), Politische Flüchtlinge in den österreichischen Printmedien. Wien, Abhandlungen zu Flüchtlingsfragen, Volume 23. 